\title{
In graffiti veritas: A paremic glance at graffiti in Tartu ${ }^{1}$
}

\author{
Piret Voolaid
}

\begin{abstract}
The article discusses the paremic (proverbial-phraseological) element in the public space in Tartu. I concentrate in particular on dynamic spaces which are freely accessible to all without any limitations (incl. important elements of urban space, such as shopping centres, cultural and leisure time centres, stations). They involve the values, symbols and signs of urban life.

The aim of my paper is to analyse the nature, proportion and meanings of the paremic matter in the following sources:

1) street graffiti, i.e. the (anonymous) drawings, scribblings and writings;

2) specific poster texts, generated by the Tartu group of the international Loesje movement, which have been glued on the walls of buildings, electrical switchboards, lamp posts, etc. in Tartu since 2004 (the poster collection is available in Estonian, English and Russian at http://www.loesje.ee).

Analysis of multi-modal texts focuses on the proportion of traditional and improvisational, local and global in paremia. The aim of the article is to explain what kind of social status, mentality and expressiveness is contained in the texts of this specific cultural phenomenon, and what are the identities, platforms, ideas, and the social reality (particular events) that these utterances are helping to reflect.
\end{abstract}

Keywords: anti-proverbs, graffiti, Loesje posters, paremiology, proverbs, proverb parodies, street art, wellerisms.

The idea to write an article about the paremic aspect of street art in Tartu, the second largest city in Estonia, is associated with the upsurge of graffiti during the recent years. In earlier days, this ancient phenomenon - graffiti was actually limited to random and spontaneous scribbles on walls, yet at the moment, it is possible to frequently notice, when moving around in the city, smart, aesthetically well-devised and masterfully accomplished graffiti works, in addition to the forms mentioned above. As a researcher of short forms of

1 The article is written with support from the target-financed project SF0030181s08 and the Estonian Science Foundation grants No. 8149 and 8137. 
folklore, I have often noticed that in a relatively large portion of graffiti texts the creator, when conveying his/her message, has used sayings, from generalised thoughts in the form of proverbs and aphorism-like quotations to humorous and juicily figurative slogans or everyday catch-phrases. Research on the contact points of graffiti and paremia has indeed been done elsewhere in the world, e.g. the connections of graffiti and proverbs have been dealt with from the political perspective (Rolston 1995; Williams 1991; Tillman 1990) and graffiti has been observed, primarily, as an abundant source of proverb-parodies in latrinalia, i.e. toilet graffiti (Dundes 1966; Nierenberg 1994); Polish mural wisdom has been studied, from the linguistic, humour-theoretical and other perspectives, by Grzegorz Szpila (2009; 2011), etc. The aim of this article is to analyse formwise the essence of the sayings in graffiti texts in Tartu, and to seek an answer to the question as to how these folkloric utterances are applied and what are the presumable socio-cultural goals that the use of paremia attempts to fill in graffiti as a communicative phenomenon.

\section{Terminology in the Estonian language}

The semantic field of the term graffiti is very wide, encompassing everything that is drawn, scribbled or written in the public space (Leete 1995). Such a broad scope of the concept, usage-wise and semantically, actually makes it possible to consider petroglyphs and other archaic semiotic techniques as graffiti, and on the other hand also include modern street advertisements, public city maps, etc. (Voolaid 1991: 1-2). In Estonian terminology, the term sometimes used to denote graffiti is kriipamine (verbatim in Estonian: scratching), suggested by Art Leete in 1995, and denoting scribbling on the walls and the activities which can be functionally equalised with this (Leete 1995: 59). Leete considers "all the messages, scratched, engraved, painted, stamped on the walls, ceilings, floors, doors, windows, stoves, tables, chairs, roads/paths, posts, etc. on streets, bus terminals, railway stations and airports, public toilets, schools, cars, buses, trains, trams, ships, and other places" as kriipamine (graffiti) (ibid.: 59). At the same time, the Estonian term is associated with scratching and scrawling as the techniques used to create graffiti and is thus appropriate in cases of scribbling, yet remains insufficient when we are dealing with large mural paintings or in situations where graffiti is artistically at a high level, both in conceptual and craftsmanship terms; its narrow semantic field is probably the reason why the term is not being widely used in the Estonian language. Moreover, the word kriipama is not listed in the orthographic dictionary (Eesti õigekeelsussõnaraamat $(\tilde{O} S))$ wherein the term graffiti is explicated as follows: 
ÕS grafiito $<7>$, grafiti $<9>$ hoone, tunneli vm seinale (hrl loata) tehtud kiri $v$ pilt (Eesti õigekeelsussõnaraamat ÕS 2006, http://www.eki.ee/dict/ qs/index.cgi?Q=grafiti\&F=M).

(a writing or picture done on the wall of a building, tunnel, etc. (usually without permission))

Graffiti can be classified pursuant to very different concepts.

Tõnis Palkov, Uku Sepsivart and Andres Siplane (2009), the compilers of the first and so far the only Estonian-language book on graffiti, talk about graffiti as a mysterious form of art which, according to a number of researchers, is part of underground-art and closely associated with youth and street culture. The authors also present the three essential types of graffiti and street art:

1) person-centred works denoting that a particular person is present or has an impact on the given area;

2) message-centred works, used to communicate certain assessments, decisions or messages;

3) spatial design works, the aim of which is to make urban space more merry and colourful (Palkov et al. 2009: no pagination (8)).

When elaborating on this thought, it is necessary to mention that these three notions can coincide, co-exist, and one of these can rule over the others. Likewise, the application of sayings can also be observed across all these three functions. Art Leete (1995), the author of the first serious Estonian-language article on graffiti, has classified the abundant collection of 3,755 graffiti texts according to their place of occurrence: bus terminal and railway station graffiti, toilet graffiti, street graffiti, interior space graffiti, vehicle graffiti, etc.; he also takes a closer look at the linguistic distribution, and highlights its most characteristic content-wise characteristics - the themes most prevalent in graffiti according to his research concern politics, international relations and pop-music. With regard to graffiti sites, the current article primarily focuses on street or open air graffiti. When summarising the content-wise classifications, suggested by different researchers, the most characteristic themes of graffiti comprise criticism of politics and the ruling power, ideologies and religion, society, life styles, school, sex, alcohol, drugs and spheres of private life (see also Szpila 2011; 2012).

It is important to bear in mind when studying graffiti that the public and society have an ambiguous attitude towards this phenomenon - on one hand, it is considered to be art, and this standpoint is also expressed when handling the graffiti as a subcategory of street art. One the other hand, however, it should be noted that in the majority of cases, graffiti is created without the permission of the owner of the surface and in such a situation, even the most masterful graffiti art is referred to as vandalism, it is punishable by law and fought against at 
the state level. However, this may not constitute a contradiction in terminology since its criminal origins do not rule out the existence of an artistic field, and vice versa. The problem, though, is much wider; international anti-graffiti seminars have been organised in Tallinn to combat this phenomenon (e.g. in July 2005), the city of Tallinn has declared a total war on any kind of graffiti and established zero-tolerance in this regard (Gnadenteich 2011). When taking photos of and recording graffiti, I have noticed the tendency that facilities and buildings neglected by their owners become graffiti sites much more frequently. In these instances, the vandal becomes as if the society's healer whose aim is to remind the owner of his/her responsibilities. On the wall of a derelict house in Pargi Street in Tartu, among other scribbled texts, there is an explicit appeal to the owner (regarding the neglected building): Tehke mind korda! ('Renovate me!') Legislative issues are irrelevant in this article, and this is why the viewpoints of graffiti artists are not presented here; the researcher's position here is comparable to that of an ordinary citizen and passerby, with the only difference that for the average town inhabitant, graffiti (similarly to advertisements) on the walls may remain unnoticed, whereas the eyes of the researcher, quite on the contrary, observe the walls.

\section{Paremic graffiti as a written context- and communication-centred cultural phenomenon}

The precondition for the context- and communication-centred approach, which became prevalent in the 1970s' folkloristic studies, has been, and still is, the requirement to treat folklore not only as the reflection of a cultural process which can be used as evidence material in the treatises of the neighbouring disciplines (e.g. by anthropologists), but also a process in its own right as well as a separate communication sphere (Ben-Amos 1971: 6). Likewise, graffiti as a written cultural phenomenon can be approached by following the most significant characteristics of folklore - it persists and disseminates within a communication process, being itself also a socio-cultural process, the inherent trait of which is constantly changing. This change, in turn, mirrors the traditional facets of the phenomenon. Context-centred analysis of graffiti actually pre-necessitates the usage of two key notions (coined by Bronisław Malinowski) - context of culture and context of situation (Ben-Amos 2009: $34 \mathrm{ff}$ ). The context of culture constitutes the framework for the perception and interpretation of folklore, and encompasses references to the joint knowledge of the presenters, regarding their behavioural convictions, belief systems, linguistic metaphors, historical awareness, ethical and legal norms, and also entails the presentation 
thereof; the most explicit context of folklore is situation (ibid.: 34). Likewise, the entire contemporary treatment of the genre is strongly related to the presentation- and context-centred approach, and as a counter-balance to the earlier atomistic approach oriented at textual units, the rethinking of the genre is more 1) systematic, rendering significance to the levels or reciprocal connectedness which organise the production and reception of communication; 2) open, observing genres as adaptable and flexible networks and 3) practice-centred, giving consideration to the discursive practices proceeding from societal life (Bauman 1992: 57).

The analysis of graffiti from a paremic aspect is a somewhat discretional approach to the whole phenomenon as it only considers textual graffiti which involves utterances in the form of proverbs or in some other sentence-like form. Paremic approach to graffiti as a written multi-modal phenomenon ${ }^{2}$ is in itself a narrow one, as it seems to presuppose that the verbal text is extracted from the whole of the work, yet the information conveyed with the help of visual means is often of extreme importance in graffiti, regarding its integral meaning and interpretation. Undoubtedly, graffiti is one of the phenomena where "the verbal language and pictorial images do not have a clear and distinct difference in their practical communicative application, instead, these two conquer each other's territories and are often mutually interdependent in their optimal functioning" (Laaniste 2005: 617). On frequent occasions graffiti is a pictorial text realised in the coexistence of the picture and the worded text, wherein both are inseparable without losing the meaning, although formally differentiable (Sarapik 2004: 22). In the light of earlier folkloristics, it would not be wrong to consider graffiti a syncretic ${ }^{3}$ folkloric phenomenon where the verbal folklore (of sayings) may, but might not always be intertwined with the elements of graffiti as an independent visual genre.

In order to determine and organise paremic graffiti, and describe the paremic aspect thereof, it is most expedient and appropriate to use the traditional category- and text-centred methods, which primarily proceed from the form. However,

\footnotetext{
${ }^{2}$ When studying communication in a real situation, multi-modality, in the broad sense, would mean all the surrounding and usable methods and means (incl. drawing and writing) that are available for the person in order to create meaning. Simultaneous, linguistic, action-based and pictorial communication can be referred to as multi-modal in general (Tenjes et al. 2009: 268). If the paremic aspect is put in the forefront upon the analysis of graffiti, it also means that the linguistic aspect is of greater relevance (as proverbs are primarily realised through language).

${ }^{3}$ Syncretism, i.e. the connection of oral creation (text) with other arts or with the elements of other arts, has been regarded as one of the specificities of folklore (Laugaste 1975: 69; Tedre 1983: 337); the modern concepts of multi-modality and multi-mediality actually convey the same content, to a greater or lesser extent; likewise, mixed or Creole text has also been used as an umbrella term for the texts that break the boundaries of traditional text genres (Torop 2008: 721).
} 
the entire socio-communicative context is just as important when attempting to provide a wider socio-cultural meaning and interpretation, and due to the specificity of graffiti (usually an illegal anonymous creation), this context can be incomplete and fragmentary. In most cases, we have no data with regard to the person who created the graffiti, although usually, the authors are of 10-12 up to 20 years of age (Szpila 2011: 324), and comprise individual amateurs like (art school) students or the representatives of subculture groupings (e.g. punks, hip-hoppers, skinheads, sports fans, rock fans). Similarly, the observer does not know usually much about the performance situations associated with the creation of graffiti, nor about the aims - the researcher can only make presumptions based on the cultural environment, according to his/her cultural competence. Yet in order to give a full interpretation, the researcher should also know and consider the author's perspective which in this article has remained relatively insufficient. The author of the graffiti is unknown to the reader, but on the other hand, the reader is also unknown to the author.

Although the author of graffiti, when creating his/her work, might not bear in mind a concrete reader, the graffiti work does have a receiver. It is indeed possible to talk about communication, the research of which has prevailingly focused on two aspects: on the conveying of messages, and on the creation and alteration of meanings (Fiske 1990: 2). The meanings and interpretations of paremic graffiti as a communicative phenomenon are of interest primarily from two points of view. The first is the viewpoint of the researcher - how and by way of what kind of theories to interpret the texts in connection with the preconditions, socio-cultural situations and reasons that lead to the creation thereof. There might be different reasons why paremic subject matter is applied in this illegal phenomenon. A true proverbial format in the case of a cognisant graffiti-creator may be associated with the desire to gain authority: due to their functions, proverbs are considered to be an authoritarian way of expression (e.g. in pedagogical speech, see Granbom-Herranen 2010: 99). Besides, humorous modifications of proverbs, being witty and playing with words, tend more easily to attract the attention of the passersby. The other is the viewpoint of the presenter - what kind of meanings do these texts acquire in certain conditions, certain situations and cultural associations for a conventional passerby, what are the real-life events that have triggered the creation of this concrete text, and how does the receiver manage to interpret these. It is important to emphasise the dynamic nature of graffiti where communication between authors is a key element of street culture - the texts are not fixed but open. Anybody who wishes to can contribute (or make additions) to the graffiti text, and the emerging dialogue may keep changing the semantic nature of the 
text, so in order to track the changes, the researchers needs to observe the text over a period of time.

In such a communication process, proverbs (sayings) can also be dealt with as a meta-linguistic code between the author and the receiver. The communicative nature of graffiti can be characterised by way of Roman Jakobson's (1981: 22) six-part scheme: addresser > text (message) - contact - context - metalinguistic code $>$ addressee. All six components are of relevance in conveying the message from the addresser (author of graffiti) to addressee (receiver of graffiti). In order to understand the message, it is necessary to know the common (cultural) context, and in order to convey the message, it is necessary that the author and the receiver share a common code (language). The transfer of the message, in the physical location of the graffiti, usually takes place asyncronically without the author and the receiver ever meeting each other. Anti Randviir has underlined the functions of graffiti - creating a territory and establishing its boundaries - and also differentiated two types: communicative graffiti, created consciously with an aim to communicate and influence the surroundings, and non-communicative, declarative graffiti, which, in appearance, seems to have no purpose (Randviir 2008: 22). At the same time, drawing a border line between communicative and non-communicative graffiti can be quite difficult for the researcher.

\section{Analysis of the subject matter}

\section{Source materials}

The primary source for the current article comprises graffiti, photographed by myself in Tartu as of the beginning of 2011. I chose the ones that I perceived to contain certain paremic elements, i.e. where it was possible to associate the (sentential) texts with proverbs (both classical as well as new modifications of proverbs) and phraseologisms (incl. quips, catch-phrases, slogans, etc.). The texts have been mainly recorded within the town centre; however, the districts Karlova and Tähtvere also demonstrated a conspicuous amount of paremic graffiti. In Annelinn, on the other hand, which is a densely populated residential area, where the walls of houses are well covered with graffiti, the paremic element did not stand out.

Graffiti texts are often full of mistakes, wimpish scribbling (or messages such as " $\mathrm{X}+\mathrm{Y}=$ love", insignificant from the viewpoint of the traditional folklore of sayings), and I was therefore relatively selective when storing the material. My object of interest was graffiti which contained sentential writings that could in 
general involve paremia. The recorded ones are short integral (often judgemental) statements, figurative generalising sentences and slogans, characteristically brief, poetic and sometimes also proverbially instructive.

The majority of the 200 photographed texts used in this study are presented only on one occasion. In analogous graffiti-studies, Polish linguist Grzegorz Szpila has analysed 100 texts, thus the amount of the subject matter is in correlation.

The sample texts are mainly in the Estonian language. The second frequent language is English - this is not surprising in Tartu where the Estonianspeaking population is ca $75 \%$ and Russian-speakers form ca $15 \%$, and the impact of English on the Estonian youth language is strong; this was also evidenced in the all-Estonian school lore collection campaign in 2007. Russianlanguage graffiti texts came only third in popularity. However, the collection also represents some marginal languages in Estonia - there was one Latvian, one Spanish and one Latin sentence, whereas part of the graffiti is macaronic, i.e. the words of several languages are used all together. The implications of international pop-culture in graffiti are indeed expressed through the use of the English language texts. Relying on his graffiti collection, Art Leete (1995: $65)$ has argued that obscenities are written on the streets on relatively few occasions (10\%), yet there are quite a lot of graffiti about politics $(6.5 \%)$ and pop-music (8.9\%). In general, the same ratio seems to be valid also today, as among the dull scribbling there are also conspicuous paremias in graffiti texts.

With regard to their technical solutions, most paremic graffiti is manually scribbled (55\%), the second frequent option is stencil-graffiti (40\%). As researchers have noted (see also Jokinen 1989: 210), stencil graffiti is generally accomplished at an artistically higher level, they are more visual, abundant in images, the pictorial material and ideas are often inspired by elements of mass media, mass culture, rock-music and figurative art, particularly cartoon art. Also throw-up or bubble-style graffiti masterpieces, usually in two colours (contour in one and the content in another) are quite frequent in Tartu, particularly in the suburbs, but they tend to consist of single words or names, instead of longer sentential phrases.

When moving around in Tartu, recurrent graffiti texts of the same handwriting are readily noticeable, which probably evidences the need of an individual or collective graffiti artist (either consciously or subconsciously) to mark the territory. An individual can recognise the area once he/she feels he/she belongs to a certain social group with a marked territory; when he/she is the author of a paricular graffiti; or when he/she feels a sense of belonging to this particular group of authors (Randviir 2008: 19). 
The local support group of an international youth movement Loesje is prominent in Tartu with their distinctive graffiti-like activities ${ }^{4}$. According to the website of the group, the Loesje movement was born in Arnhem in the Netherlands, on Thursday, 24th of November, 1983. Since 2004, special poster-texts, generated by Loesje-Tartu, have been stuck on the walls of buildings, electrical switchboards, lamp-posts and elsewhere in the town (the poster collection comprises parallel texts in Estonian (425 texts), English (281 texts) and Russian (224 texts) and is available at http://www.loesje.ee).

The messages and the content are conveyed in a characteristic way - an A4 sheet with the text written in black capital letters, no punctuation, and the signature Loesje.

More precisely, the idea was actually conceived as early as in the spring of 1983, when nine people came together in Arnhem. The aim of the group was to devise a new type of initiative in order to do something against the then critical political situation. The girl's name Loesje was chosen to make the texts more personal, distinct, and to simplify the idea. Besides the Netherlands, the Loesje movement is now also operating in several European countries: Belgium, Latvia, Poland, France, Sweden, Serbia, Finland, Belorussia and Russia. The Estonian affiliate of the NGO Loesje commenced on the 1st of April 2004, with the headquarters in Tartu, yet the other regions of Estonia, incl. Tallinn and Ida-Virumaa, are also taking part in the work, participating actively in international projects.

The poster texts are devised in relevant workshops which take place about once a month, in group-work and as collective creation. Indeed, it is underlined that each text is an outcome of a collective creative process which finally ends up in the public space under the name Loesje. The members of the movement, generally young people, and mostly students, split into two categories - workshops are conducted by the so-called trainers or supervisors, and the participants are the ones who write. In Estonia, Loesje started operating in the Russian language, but soon the Estonian-speaking supervisors of workshops also joined in. If there are foreign guests in the group work, the outcome would be posters either in English or German.

The guidance in creating poster texts can be obtained from a special manual (see Loesje 2006), which contains systematic tips for writing good texts. The idea for these statements or slogans is not to start a new revolution but instead to make young people think, let them speak out for themselves and express their views on society. The workshops are conducted corresponding to strict rules and a fixed time schedule: the writing takes places in sequential phases,

${ }^{4}$ When describing the activities and text creation methods of Loesje, I rely on the thematic interview with active members of Loesje Tartu group, Julia Barsukova and Valeri Koort. The interview was made in March 2012. 
starting with a warm-up and aimless writing, followed by brainstorming to ascertain the central themes for posters, where consideration is given to clarity, shortness and topicality. Each theme is written on a sheet of paper. During the brainstorming session, the papers circle among all participants who inspire each other, and it is forbidden to criticise or mock others. The messages on posters are very diverse, from humorous texts with no in-depth meaning to strong socio-critical ideas.

The sites for posters are chosen according to the background, to make the posters more prominent. A white sheet of paper with black text on it is particularly distinctive on a colourful background and this is why the posters are often glued onto old concert advertisements. Indeed, the white sheets of the Loesje movement can be seen in the vicinity of other posters, on bus stops and advertisement pillars.

When analysing the Loesje posters, I have on the one hand relied on the photographs taken in the town (ca. 20 recordings), and also on the posters that have been uploaded on the movement's homepage since 2004, forming a noteworthy and considerable source.

\section{Structural classification of the subject matter}

Generic boundaries, between Estonian proverbs and (proverbial) phrases, are generally extremely ambiguous (see Krikmann 1997: 52), however, according to common understanding, a proverb is a generalising sentence, whereas a phraseologism is a part of sentence, in the syntactical sense. The recorded graffiti texts allow us to identify syntactic formula patterns which refer to the existence of the paremic element. The following is an attempt to classify the collected matter into formula-based categories.

A. The largest group is formed by indicative statements, generalising sentential implications.

Ainult matsid sodivad seintele. Intelligendid joonistavad

Only bumpkins scribble on walls. Intellectuals draw

Ilusatest mõtetest sünnivad ilusad asjad

Beautiful thoughts give birth to beautiful things

Etikett on konservidele

Etiquette is for tinned food

Tühi sein on kole sein

Empty wall is an ugly wall 


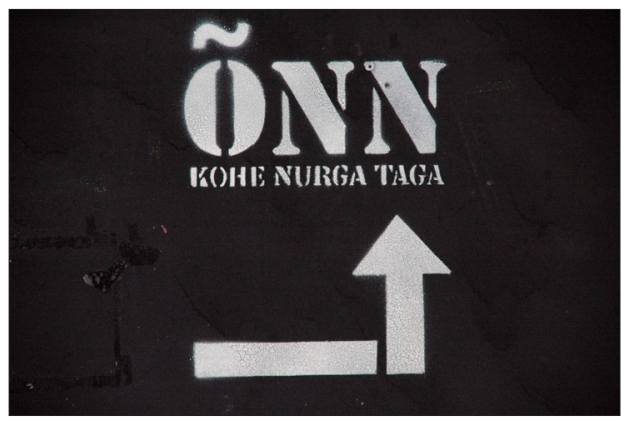

Õnn kohe nurga taga ('Happiness right around the corner'). This graffiti text is repeated in several places, yet the surrounding context gains specific relevance in the case of the graffiti drawn at the corner of Tähe and Õnne streets, where the physical Õnne Street ('Happiness Street') and abstract happiness may coincide. Joint a day keeps the doctor away. Self-evidently, this is a modification of one of the most popular medical proverbs An apple a day keeps the doctor away. According to Wolfgang Mieder, this saying, which gives a tip for healthy nutrition, gained popularity at the beginning of the 20th century, and is actually itself also a modification of a saying known in English as "Eat an apple on going to bed, and you'll keep the doctor from earning his bread", first published in the journal "Notes and Queries" (see Mieder 1991: 97). Likewise, Mieder also concedes that the formula "X a day keeps the $\mathrm{Y}$ away" is very widespread nowadays. Thus it is not at all surprising that this formula, applied to narcotic substance cannabis, has been used on the graffiti in Tartu.

Hereby it is expedient to note that upon closer observation, the anonymous graffiti texts and the Loesje posters actually include quite a lot of proverb modifications, the main aim of which is not to be instructive but instead witty, surprising, novel and humorous. For instance, some words in a known classical proverb are altered, the other half of the proverb is changed, or a subordinate clause is added to a simple-sentence proverb, altering the actual meaning. In paremiology, such modifications have been referred to as proverb parodies (see, e.g., Krikmann 1985: 474-483) and also as anti-proverbs (Litovkina \& Mieder 2006; Mieder 2008: 87-119). Several of the Loesje posters also fall into this category:

VALEL ON LÜHIKESED JALAD AGA PALJUD EI NÄE SEDA TEMA SOENGU TÕTTU

LIE HAS SHORT LEGS BUT MANY DON'T SEE THAT BECAUSE OF ITS HAIRDO

HEAL MÕTTEL ON ILUSAD SILMAD

GOOD THOUGHTS HAVE BEAUTIFUL EYES 


\title{
IGAÜHE UNEL ON OMA NÄGU \\ EVERYONE'S DREAM HAS ITS OWN FACE
}

\author{
RASKE JÕUSTIKUS, KERGE LAHINGUS \\ HEAVY IN ATHLETICS, EASY IN BATTLE
}

The group of generalised statements also involves defining and generalising statements, where the basis for the generalisation is the main metaphoric formula of cognitivists, "A is B", expressing 1 ) either the sameness of two notions, or 2) a categorising statement - placing one object in a category according to similarity, or mapping a superordinate into a super-category (cf. also Turner 1991: 196-197, 199).

Iga konstruktsioon on helijada

Every construction is a sequence of sounds

Kumm on püstol, mis tapab su lapsed. HIVi pole neil, kes väljaspool abielu ei seksi / Rezinki - pistoletõ, ubivajushtshie tvoih detei. VICHa net u teh kto ne zhivjot polovoi zhiznju vne braka!

The rubber is a pistol that kills your children. Those who do not have adulterous sex have no HIV

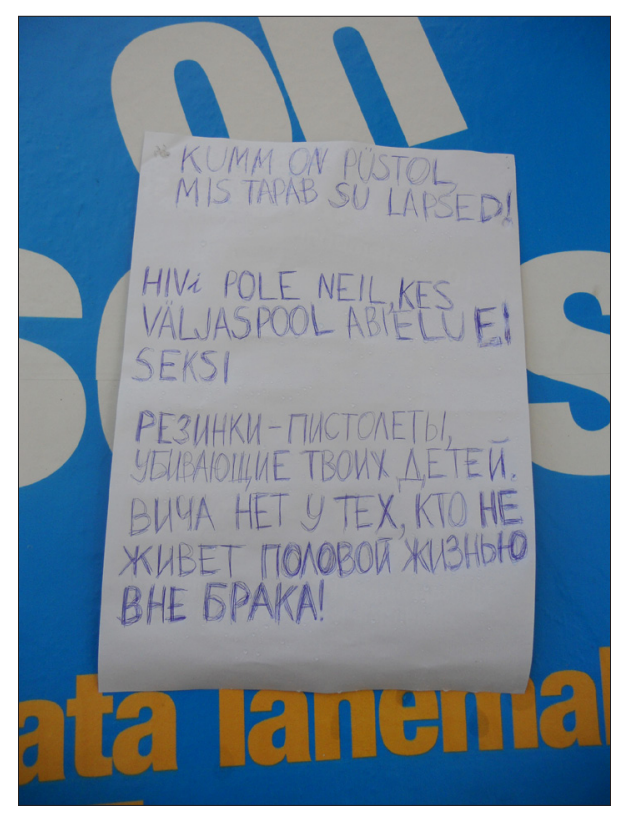


The poster with this text is a response to the prevention campaign "Rubber is sex", organised by the National Institute for Health Development in the autumn of 2011, widely covered by the media and provoking the wider public. Colourful eye-catching street advertisements with the slogan "Rubber is sex" were installed everywhere, and the above-presented text was manually written on an A4 paper, and glued all over the advertisement board. As mentioned earlier, the original advertisement caused major resonance among the public and in the media, and the sample text is actually an example of counter-measure to the message in the advertisement.

This sub-group also entails a number of defining statements about life, e.g.:

Elu on drumpäss. Norm.

Life is trump ace. Norm.

Elu on huvitav.

Life is interesting.

Elu on lill, ainult kasta!

Life is flower, only water it!

Loesje text:

ELU ON KAKTUSE LILL

LIFE IS THE FLOWER OF CACTUS

Elu on täpselt nii ilus, kui ilusaks sa teda mõtled.

Life is just as beautiful how beautiful you think it to be.

Tere... Õlu on elu alus, arvab Sannu.

Hello... Beer is the basis of life, thinks Sannu.

Love is concrete - the location of this graffiti text, on the concrete wall of the Vabaduse Bridge, creates a multi-layered wordplay.

In frequent occasions, negation is used in the statements.

Miski pole olulisem kui see lause

Nothing is more important than this sentence

Kunst ei ole kunsti teha, kunst on kunstis kunsti näha

There is no art in making art, the art is to see art in art

Inspired by works of René Magritte, a Belgian artist, there are several pieces of graffiti where the pictorial images are supported by verbal negating statements: 


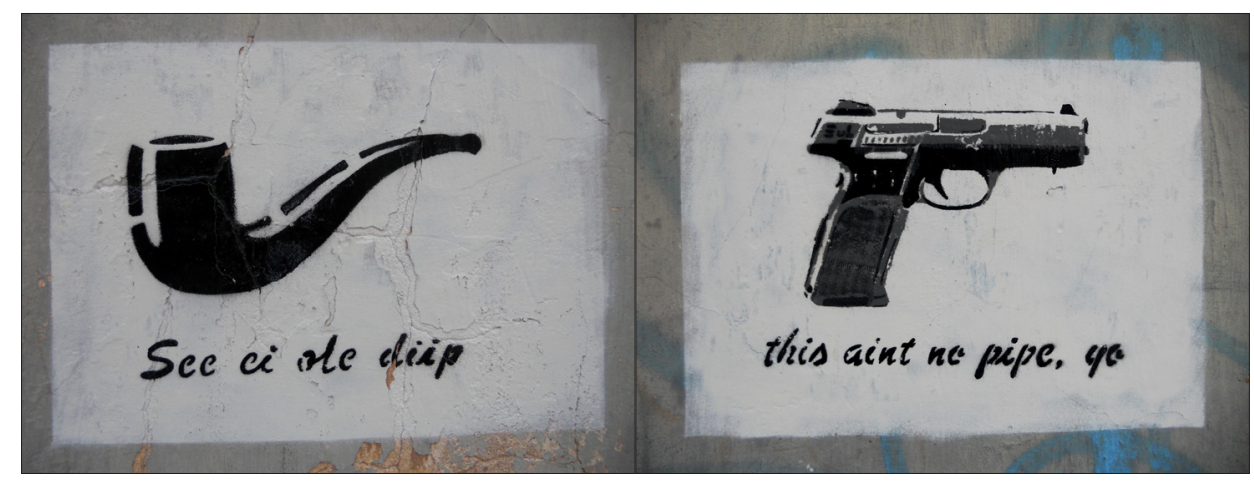

See ei ole diip / this aint no pipe, yo

This is not deep / this ain't no pipe, yo

(deep rhymes with piip, which is Estonian for pipe)

A Loesje poster with a negation is, for instance:

\section{ÕIGE ABIELU POLE MINGI KAIKAVEDU}

\section{A PROPER MARRIAGE IS NOT A TEST OF STRENGTH}

This sub-category of defining statements allows us to draw parallels with the graffiti texts of the 1980s on the walls of Tallinn and Tartu, which, written by Ülo Kiple, focused on the "cure of diseases" and "truth of gods", and made the author well known all over Estonia. However, after his death, his work was continued by other graffiti artists. The messages about the cure of diseases, in different versions, encompassed a lot of different religious-philosophical aspirations, including the utterances which defined abstract notions (see also Leete 1995: 65; Palkov et al. 2009).

B. Among the graffiti in Tartu, there is a relatively representative collection of author's quotations and aphorisms-maxims which, to a great extent, are generalised words of wisdom. In rare instances, the writing is also equipped with the name of the author of the maxim, yet in most cases, this is left unwritten, and the guessing and interpretation depends on the intelligence of the reader. The majority of graffiti statements seem to be originating from fiction, while some of the texts have been inspired by words of philosophers, well-known educationalists, opinion leaders, and a part of the texts are derived from popular or not-so-popular songs, etc. The most frequent and repeated author's quotation on the walls of Tartu is the rhetorical question by the American writer Henry David Thoreau: Milleks see kiire, mis kuhugi ei vii? ('Why should we live with such hurry and waste of life?'), created in stencil-technique and at places illustrated with the image of a snail. Indeed, for the hurrying passerby, this graffiti might provide an insightful moment. The same text is displayed on the 

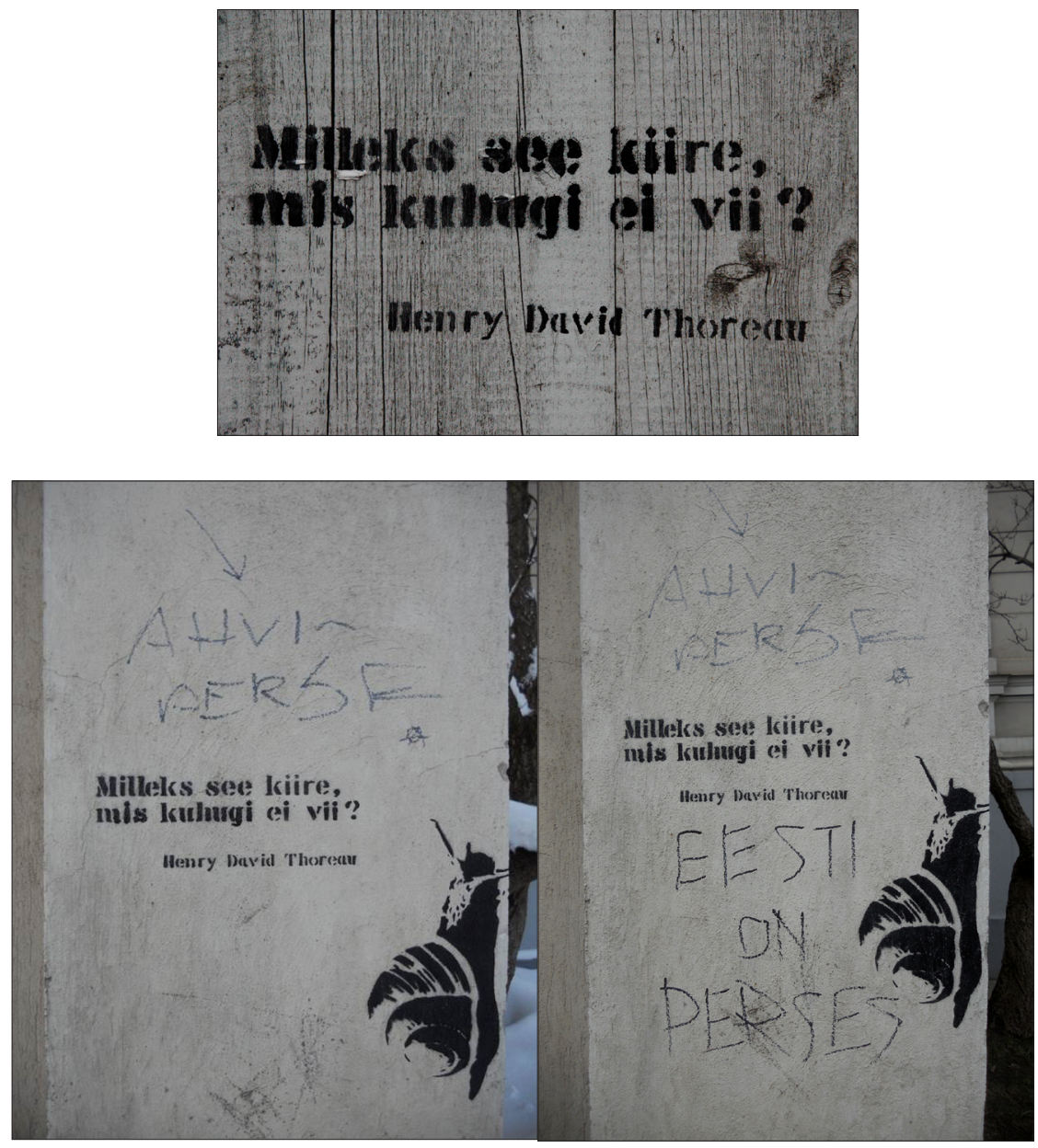

wall of the House of Writers' Union in Tartu, illustrated with a snail (actually, the snail appeared before the text). It is interesting to note that this piece of graffiti was later adorned by additions by several authors (first, a block letter scribbling "monkey's ass", and then a political addition "Estonia is screwed [in the ass]"), which have a syncretic effect.

Just meie meeled - mitte meie mõistus - annab meile teadvuse ning meie eksistents - mitte meie tegevus - annab meile vä̈̈rtuse. Karl Grunewald It is our senses - not our mind - that gives us consciousness and it is our existence - not our action - that gives us value. Karl Grunewald

Täna on parim päev banaanikala pü̈̈dmiseks

A perfect day for bananafish

(Jerome David Salinger, "Perfect Day for Bananafish") 
Vaid südamega on võimalik näha selgesti. Kõik tõeliselt oluline on silmale nähtamatu.

It is only with the heart that one can see rightly. What is essential is invisible to the eye. (Antoine de Saint-Exupéry, "The Little Prince")

Pole paremaid, halvemaid aegu, on vaid hetk, milles elame praegu

There are no better or worse times, just the moment we live in

(Estonian poet Artur Alliksaar)

The statement Aeg lendab, sina oled piloot ('Time flies, you're the pilot'), found on a derelict building on Pargi Street, and "uttered" by the popular cartoon character Smurf, was apparently inspired by the thought of Michael Altshuler, a trainer and management teacher, which in English reads as follows: [The bad news is] time flies. [The good news is] you're the pilot.

Still, when trying to comprehend the entire context, the question arises whether the combining of Smurf and Altshuler's quotation serves a particular purpose, but bearing in mind that, at the time, the film "Smurfs 3D" was shown in the cinemas, such a coincidence does not seem to be so peculiar.

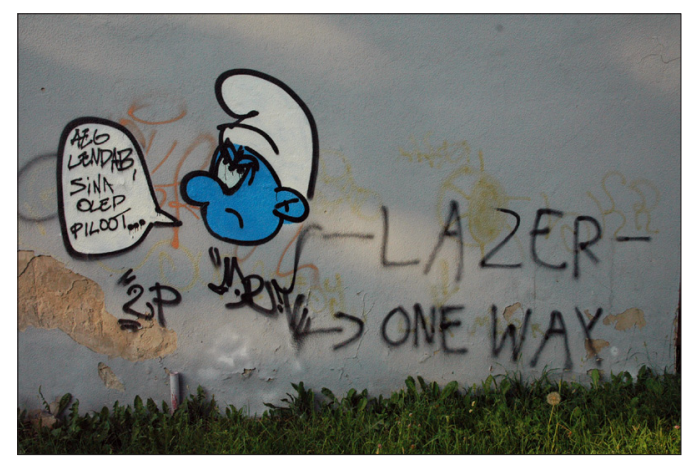

Loomulikult see asjaolu, et rohutirtsud ja nende sugu on söödavad, selles on väga suur sanitaarepidemioloogiline, dietoloogiline, kulinaarne tõde. Naturally, the fact that grasshoppers and their genus are edible, this entails an enormous sanitary-epidemiological, dietological, culinary truth. (Estonian zoologist and ethologist Aleksei Turovski)

Katsuge oma aeg üle elada nii, et elu teid ei leiaks. K.K.

Try to survive your time so that life would not find you. K.K. (Estonian writer Kalev Kesküla, "Elu sumedusest” ('The Mellowness of Life'))

Creation is God exploring God's self through every way imaginable (Mellen-Thomas Benedict) 
With strange [a]eons even death may die!

(This line is from "The Nameless City" by the American horror and science fiction writer H. P. Lovecraft, and also a verse from the song of Metallica, "The Thing That Should Not Be". Presumably, it was the latter that has inspired the writing on the wall in Tartu.)

Miski pole olulisem kui see lause.

Nothing is more important than this sentence.

Displayed on the wall opposite the Tartu Central Library on Kompanii Street, the text originating from writer and linguist Erkki Luuk (from the 2003 collection of poems „Ornitoloogi pealehakkamine“ ('Undertak-

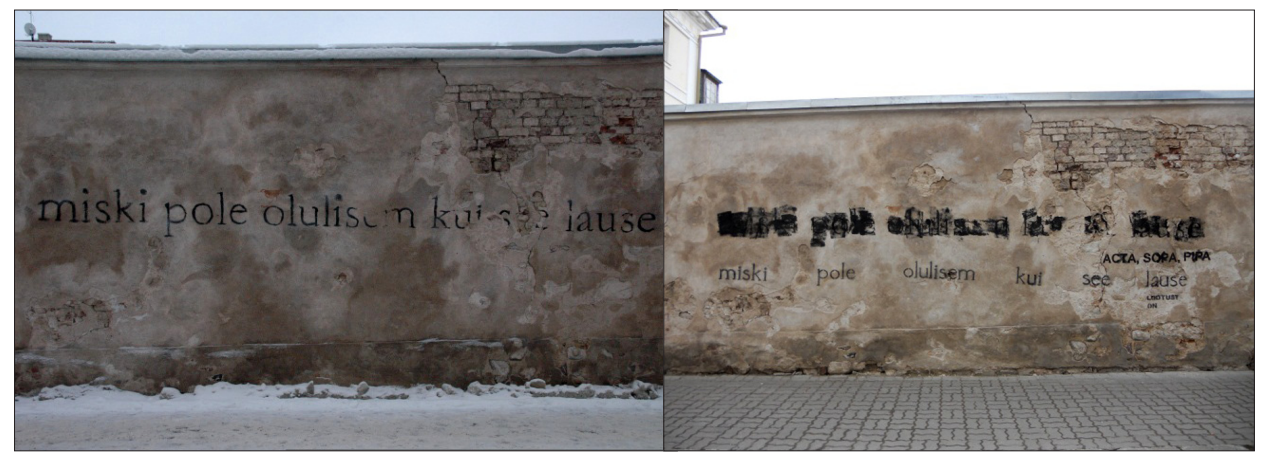

ing of an Ornithologist')). "Nothing is more important than this sentence" is an interesting example of the dynamic and communicative potential of a piece of graffiti. On January 29, 2012, a local street artist Edward von Lõngus painted the text over in black and signed with the acronyms ACTA, SOPA and PIPA. His actions were filmed and photographed; the video was uploaded to youtube.com (http://www.youtube. com/watch?v=ErexnKuwam8). According to the artist, he was "forced to censor the text in protest of the legislative proposals known as ACTA, SOPA and PIPA." (see Lõngus 2012). This led to a lively discussion in

\footnotetext{
5 There were currently ongoing discussions, in the USA and worldwide concerning the ratification of an international agreement which was meant to combat piracy of intellectual property (the agreement would have permitted private companies to patrol their internet traffic) - ACTA (The Anti-Counterfeiting Trade Agreement). This coincided with the discussions in the USA about a law proposal that was claimed to stand for the rights of the entertainment industries - SOPA (Stop Online Piracy Act) and PIPA (Protect IP Act). On February 11, 2012, anti-ACTA demonstrations were held all over world, including Europe and Estonia.
} 
artistic circles (see, e.g., Tammemäe 2012). After a while, the overpainted sentence and acronyms were undersigned with the original text and below it in block letters "THERE IS HOPE". Due to a convergence of time and social events, the text became a social critical dynamic sign employed by several authors: censoring gave the original message an additional dimension, after which de-censoring and additional comments made it part of a discussion.

There are also some paraphrases of the author's quotations among the Loesje texts:

TULIN NÄGIN JA JÄIN VAATAMA

I CAME, I SAW AND I STARED

(Paraphrase of the statement attributed to Julius Caesar, Veni vidi vici)

KA KULUNUD SAAPAD JÄTAVAD JÄLJE

EVEN WORN BOOTS LEAVE A TRACE

(This is an obvious reference to Estonian poet Karl Ristikivi's verse line - "Ka sisaliku tee kivil jätab jälje" ('Even the lizard's track over the stone leaves a trace').)

C. Self-centred graffiti is another syntactic sub-category worth mentioning. The texts emanating from the ego-position can be abundantly found on the streets, and this is supposedly a direct reference to the fact that graffiti, as a phenomenon, is a form of as self-expression. Usually, these texts reveal personal wishes and desires of the graffiti-maker, but they can also be generally humane and superficial, without any reference to specific persons. These texts have no explicit connection with proverbial subject matter; however, apart from purely practical wishes and desires, in some instances, these individual-centred writings may also convey broader philosophical aspirations which make them closer to aphoristic flows of thought.

Igatsen valgust

I miss light

Öösiti otsin valgust

I search for light at night

Kardan pimedas koju minna

I'm afraid to go home in the dark

The texts indicating a yearning for light and fear of the dark appeared in the Tartu city scene as the city shortened the time street lights worked at night in order to cut costs during the economic downturn. 
See, mis mind õnnelikuks teeb, ei ole mitte armastus, mida teised minu vastu tunnevad, vaid armastus, mida mina teiste vastu tunnen.

What makes me happy is not love that the others feel for me, but the love that I feel for others.

Mul on suurem kui sul

Mine is bigger than yours

Loen teiste seintelt

I read from the walls of others

Tahaks künda

I'd like to plough

Ma ei taha nii vähe

I don't want that little

Armastan kollaseid sokke

I love yellow socks

Mina usun teisse

$\mathrm{I}$ believe in you

I smoke because it's cool

D. You-addresses form a significant part of the texts whereby the graffitiartist does not write the message for him- or herself, but for the observer, and this confirms the communicative function of graffiti.

Sa oled nagu action man. Blondid juuksed, kandiline soeng ja püksis ei midagi ... Mõistusele on sul kõige lähemal reha, äärmisel juhul labidas. You are like an action man. Blond hair, square hairdo and nothing in the pants ... What resembles your mind the best is a rake, or in an extreme case, a spade.

Oma sõbrad leiad ööst...

You'll find your friends in the night...

Google has you 


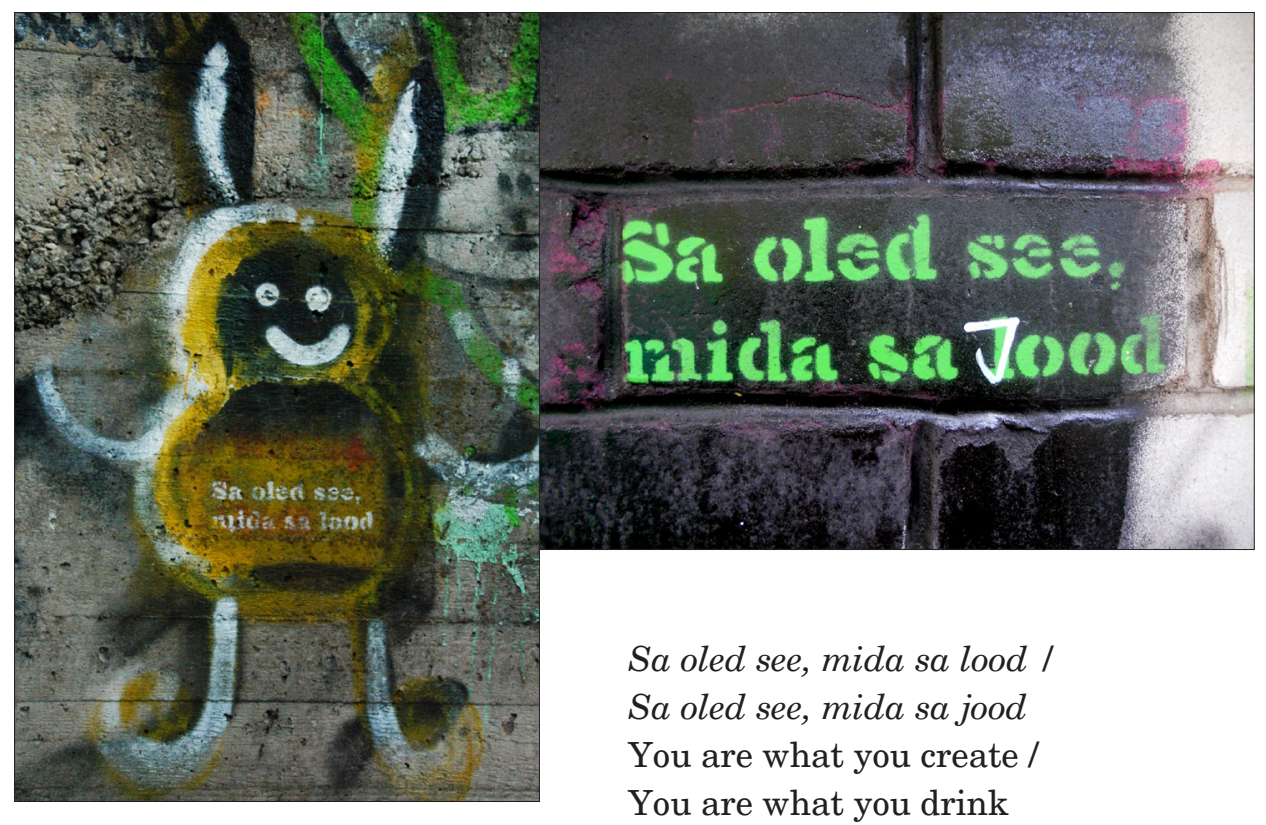

The last text is a modification from the internationally known saying - You are what you eat - and an exquisite example of the communicative nature of graffiti. "You are what you create" is one of the most recurrent apothegms on the streets of Tartu, and the scribbling on one of the relevant graffiti texts in Pargi Street, altering a letter, has created a new meaning: the j-letter is written on top of the l-letter, thus making the word "lood" ('create') into "jood" ('drink'). This text is good proof of the accumulating nature of street art - new pictures are added to the once "opened" wall, and existing texts and pictures are also being supplemented.

With regard to the modal exterior form, proverbs tend to be mostly indicative statements or generalising implications, yet there are also syntactic forms being used, e.g. questions or imperatives. The examples of the sentences which address the passerby-reader-addressee and are imperative, in some instances, are as follows:

Hinga vabalt, ela tõeliselt, armasta

Breathe freely, live truly, love

Pange see kool põlema

Put this school on fire

Ära sodi seina, seinal on ka tunded!

Don't scribble on the wall, the wall has feelings! 
Eat fast, die young

Live by the gun, die by the gun

Likewise, on frequent occasions, the Loesje texts also involve imperatives:

OLGE ALDID VASTU VÕTMA UUT ELUTUNNETUST SIIS SÄILITATE OMA NOORUSLIKKUSE JA VISUAALSUSE

BE EAGER TO ADOPT THE NEW COGNIZANCE OF LIFE AND YOU'LL MAINTAIN YOUR YOUTHFULNESS AND VISUALITY

SEIKLE KODUS LIHTSALT TÕUSE VOODIST ÜLES

HAVE ADVENTURE AT HOME SIMPLY GET UP FROM YOUR BED

ÄRA MAALI TEISEST INIMESEST JÄÄLILLE

DON'T PAINT AN ICE FLOWER OF ANOTHER PERSON

ELUTEATRIS LAVASTAD OMA ELU ÄRA LAVASTA END SÜÜDI

IN THE THEATRE OF LIFE YOU DIRECT YOUR LIFE DON'T STAGE YOURSELF GUILTY

KEVAD TOMATI ISTIKUTEL ALGAB ISESEISEV ELU ÄRA J̈̈̈̈ TAIMELE ALLA

SPRING TOMATO PLANTS START WITH INDEPENDENT LIFE DON'T BE OUTPERFORMED BY PLANTS

JÄLGI MIDA TEED LASTELE MEELDIB JÄRGI TEHA

WATCH WHAT YOU'RE DOING CHILDREN LIKE TO IMITATE

Addressing rhetorical question-like thoughts-sentences are as follows:

What life will you choose the wizard or the goose

?Como te sientes?

How do you feel?

Kas sina oled mind juba toitnud?

Have you already fed me?

Question-like texts on Loesje posters are, for example, the following:

KAS SAMMUMÕÕTJA MÕÕDAB EDUSAMME

DOES PACECOUNTER MEASURE ADVANCEMENT 
KAS OLED JUBA OSTNUD PATTUDEST VABASTAVA JÕULU$K A A R D I$

HAVE YOU ALREADY BOUGHT THE CHRISTMAS CARD RIDDING YOU OF SINS

KAS TEIE TREPIKOJAS ON JUBA KUNSTNIKUTÕRJE TEHTUD HAS ARTIST CONTROL ALREADY BEEN DONE IN YOUR FLIGHT OF STAIRS

KASVUHOONEEFEKT KAS SA JUBA EHITAD ENDALE NOA LAEVA GREENHOUSE EFFECT ARE YOU ALREADY BUILDING A NOAH'S ARC FOR YOURSELF

Clear-cut laconism, imperative mode and interrogative aphorisms are tools used in graffiti, and also in commercial texts, to attract the attention of passers-by, and to be remembered.

E. On frequent occasions, the graffiti texts represent syntactic stereotypes or syntactic formulas intrinsic to classical proverbs, which, regarding the prerequisite and conclusion part, also highlight the syntactic symmetry of proverbs:

Kes ..., see ...
Who ..., is/does ...

Kes vahib seda, on pede / Kes seda loeb, on pede

Who watches this is gay / Who reads this is gay

(This peculiar value-judgement is one of the most frequent ones written on the walls in Tartu.)

Kui ..., siis ...

If ..., then ...

Koit Toome näeb, kui sa siia pissid

Koit Toome will see if you piss here

Similarly, some of the Loesje proverb parodies also follow these symmetric pattern formulae:

Kes ..., see ...

Who ..., is / does ...

KES NAERAB MILLEGIPÄRAST, NAERAB PAREMINI

HE WHO LAUGHS WITH REASON LAUGHS BETTER 
KES ARMASTAB SEE KAUA ELAB

HE WHO LOVES LIVES LONGER (modified proverb)

Parem ..., kui ...

Better ..., than ...

PAREM KAKS KÜÜNALT LAUAL KUI SADA PIRNIS

BETTER TWO CANDLES ON THE TABLE THAN A HUNDRED IN THE BULB

PAREM HAMBAHARI PEOS KUI HAMBAD KATUSEL

BETTER TOOTHBRUSH IN THE HAND THAN TEETH ON THE ROOF

PAREM SUPP KÕHUS KUI PUDER MÕTETES

BETTER SOUP IN THE STOMACH THAN PORRIDGE IN THOUGHTS

PAREM KURG TAEVAS KUI PILT INTERNETIS

BETTER STORK IN THE SKY THAN PICTURE ON THE INTERNET

Kui ..., siis ...

If ..., then ...

KUI EI SAA PÜÜDA SÕNA PÜÜTAKSE ÜTLEJAT

IF IT IS IMPOSSIBLE TO CATCH THE WORD THEN THE ONE WHO

SAID IT WILL BE CAUGHT (proverb)

KUI RAHA OLEKS RIKKAM ARMASTAKSIN TEDA KINDLASTI

IF MONEY WAS RICHER THEN I WOULD DEFINITELY LOVE HIM

Mida ..., seda...

The more ..., the more ...

MIDA ROHKEM VALGUST SEDA ROHKEM NÄEB LÄBI

THE MORE LIGHT THE MORE TRANSPARENCY

\section{F. Loesje-posters with elements of wellerism}

According to classical understanding, wellerisms are the phrases the general format of which is "A," said B, as / when $C$... happened did saw ... ("A lot of noise, a little wool," said Devil when he sheared the lamb), whereby traditional proverbs are used in a peculiar, comic, parodying context (the term was derived 
by Archer Taylor (1931: 201) from the name of the character of Samuel Weller, in Charles Dickens's “The Posthumous Papers of the Pickwick Club”, who used a lot of them in his speech). Researchers have argued that wellerisms are one of the most abundant sources of anti-proverbs (see also Nierenberg 1994: 545). The following Loesje-posters have obvious features characteristic of wellerisms:

SIIS TULEB ARMASTUS ÜTLES SIPELGAS JA TÖÖTAS EDASI (TAMMSAARE)

LOVES COMES ONLY AFTERWARDS, SAID THE ANT AND CONTINUED WORKING

TEHKEM NALJA HÕISKASID EESTLASED SURMTÕSISELT LET'S JOKE SHOUTED ESTONIANS WITH DEADLY SERIOUSITY

NAERATAGEM HÕISKASID EESTLASED SURMTÕSISELT LET'S SMILE CHEERED ESTONIANS WITH DEADLY SERIOUSITY

PÄ̈̈STKE MIND HÜÜAB ENDINE VANG VANGLA VÄRAVAS SAVE ME CRIES A FORMER INMATE AT THE PRISON GATE

GRAAFIKAT TEHA ON PÄRIS KALLIS ÜTLES PEAMINISTER SEADUST ALLKIRJASTADES

IT IS QUITE EXPENSIVE TO DO GRAPHICS SAID THE PRIME MINISTER ON SIGNING THE LAW

Considering the generally laconic and striking nature of graffiti texts, the paremic format is indeed suitable for them. There are, however, also more lengthy graffiti texts on several houses in Tartu, presenting a really allegorical narrative which ends with a moralising thought that good beats bad always:

kaks poissi, hea ja paha, loopisid teineteist kividega. hea poiss viskas pihta 8 kivi, paha poiss aga sai heale pihta ainult 5 korda. Moraal: hea võidab paha alati.

two boys, good and bad, threw stones at each other. The good boy hit the other with 8 stones, the bad boy only hit the good one 5 times. Moral: good beats bad always.

A similar story, in anecdotal format, is spreading in different versions, whereas the graffiti text is much more serious than the following version, recorded from the Internet:

Hea ja Paha istuvad pargis ning sülitavad maha, Hea sülitab 4 korda, Paha sülitab 3 korda. Möödaminev vanamees hakkab nendega pahandama. Sellepeale Hea ja Paha hakkavad vanamehe pihta sülitama. Hea 
saab 7 korda pihta, Paha saab 4 korda pihta. Loo moraal - Hea võidab alati Paha.

Good and Bad are sitting in the park and spitting on the ground, Good spits 4 times, Bad spits 3 times. A passing old man starts scolding them. In response, Good and Bad start spitting at the old man. Good hits 7 times, Bad hits 4 times. The moral of the story - Good always beats Bad. (http://www.score.ee/main.php?pID=68\&cID=4\&ms=4959)

\section{Contextual references}

These examples give evidence that the content range of paremic graffiti texts is extremely diverse - everything in the society can inspire graffiti-writers, they express their political convictions, ideological and religious standpoints, protest against the ruling power, and focus on different obscene taboo-themes, sex, alcohol and drugs, school, lifestyles-subcultures, spheres of private life.

One graffiti-text may simultaneously contain references to several themes, yet the understanding and interpretation of the text depends on the knowledge of the background, and often on the skill of knowing the "secret language".

When delving into the relevant background, it is possible to argue that the graffiti-writer has been inspired by the first lines, I have no implants! You silliest bitch! (see illustration on this page) of the electro-house style song by Marco Tasane, a stripper, musician and yellow press star.

The collection of Loesje poster texts makes it possible to diachronically encompass their socio-cultural background, and the knowledge regarding the time of writing of these texts allows us to interpret them in their synchronous time context, whereas the sources of inspiration can be guessed pursuant to specific events in society or topical problems of the time.

The first Loesje workshop, for Estonianlanguage posters, took place on May 16, 2004. The Eurovision final song contest had taken place the day before, on the 15th of May, thus it is not surprising that the subject matter was also reflected on a some posters: EUROVISIOON MIS ON SELLE SEOS MUUSIKAGA ('EUROVISION WHAT CONNECTION DOES IT HAVE WITH MUSIC'). The outcome of the second workshop, on May 20, 2004, was a poster with the text

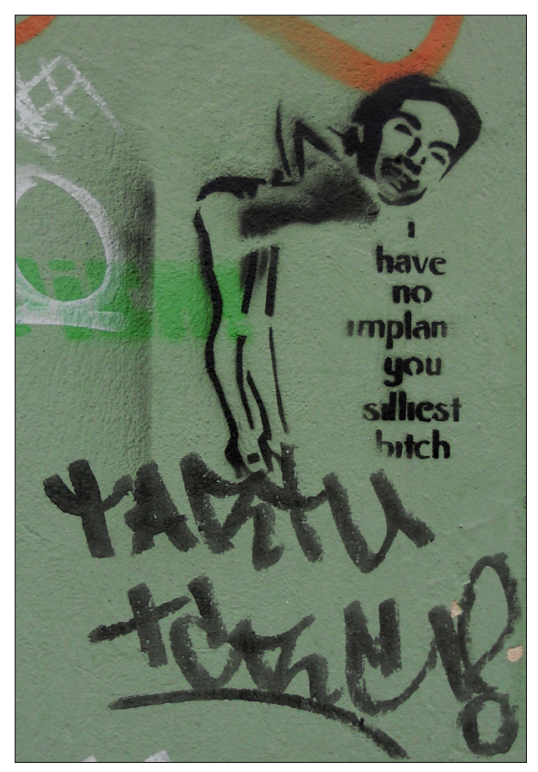


EUROLIIT KÕIK ALGAS SUHKRUST ('EUROPEAN UNION EVERYTHING STARTED FROM SUGAR').

The price of sugar soared at the time when Estonia was about to join the European Union, extensive purchasing of sugar prior to the date of accession resulted in a substantial fine for Estonia from the EU.

Posters created on May 4, 2007 are a good example of context-centred manifestations, as the permeating theme therein involves the issues concerning the riots as a response to the removal of the Bronze Soldier monument in Tallinn, in April the same year. ${ }^{6}$

ARMID PRONKSIS EI TASANDU

SCARS DO NOT SMOOTHEN IN BRONZE

MIKS POLE MÄLESTUSSAMMAST TUNDMATULE KINDRALILE WHY IS THERE NO MONUMENT TO UNKNOWN GENERAL

KUI TÄHTEDEGA MÄNGITUD HAKATAKSE MÄNGIMA KIVIDEGA ONCE YOU HAVE PLAYED WITH STARS YOU START PLAYING WITH STONES

SÕNA ON LASK NAERATUS ON KUULIVEST

A WORD IS A SHOT A SMILE IS A BULLETPROOF VEST

TUNNEN HÄSTI OMA NAABREID NEID ON VIST VIIS

I KNOW MY NEIGHBOURS WELL THERE ARE PROBABLY FIVE

OF THEM

\section{TUNTUD MÄLESTUSSAMMAS TUNDMATULE SÕDURILE KNOWN MONUMENT TO AN UNKNOWN SOLDIER}

\section{SÕNAVABADUSE VÄLJAK \\ FREEDOM OF SPEECH SQUARE}

The Bronze Night events shocked Estonian society, and also caused a major upswing in folklore creation, among the population, in the media and on the Internet. In the case of certain real-life events, poster-texts can function as a medium which expresses the collective sense of humour, historically established societal and cultural relationships, and in critical situations, the texts can also provide psychological alleviation and group therapy-like impact, both for the creators and for the receivers of these texts.

6 The relationships of folklore and reality (incl. real-life events) have been in the focus of a number of research papers; with regard to the conundrums inspired by the Bronze Night events, see, e.g. Voolaid 2011a and Voolaid 2011b. 
The introduction of the euro, at the outset of year 2011, inspired another thematic poster cycle, completed as a result of group work on November 23, 2010:

EURO NEID ON PALJU JA NAD ON TULEMAS

EURO THERE ARE MANY OF THEM AND THEY ARE COMING

EURO VÄHEM RAHA ROHKEM METALLI

EURO LESS MONEY MORE METAL

EURO HEAD ISU KALLIS RAHAKOTT

EURO BON APPETIT DEAR WALLET

KILISEB KOLISEB EUROKELL

JINGLES AND TINGLES THE EUROBELL

\section{EURO ON DEMOKRAATLIK MILJONÄRIDE HULK VÄHENEB EURO IS DEMOCRATIC THE NUMBER OF MILLIONAIRES DE- CREASES}

The underlying theme of the posters created in the workshop on the 11th of April 2010 was ecology and green lifestyle, noticeable, besides texts, also in the design and layout of the posters. All of a sudden, green pea-pods (a logo used by students of Estonian University of Life Sciences landscaping architecture and environmental protection) are now depicted on the usually black-and-white Loesje posters:

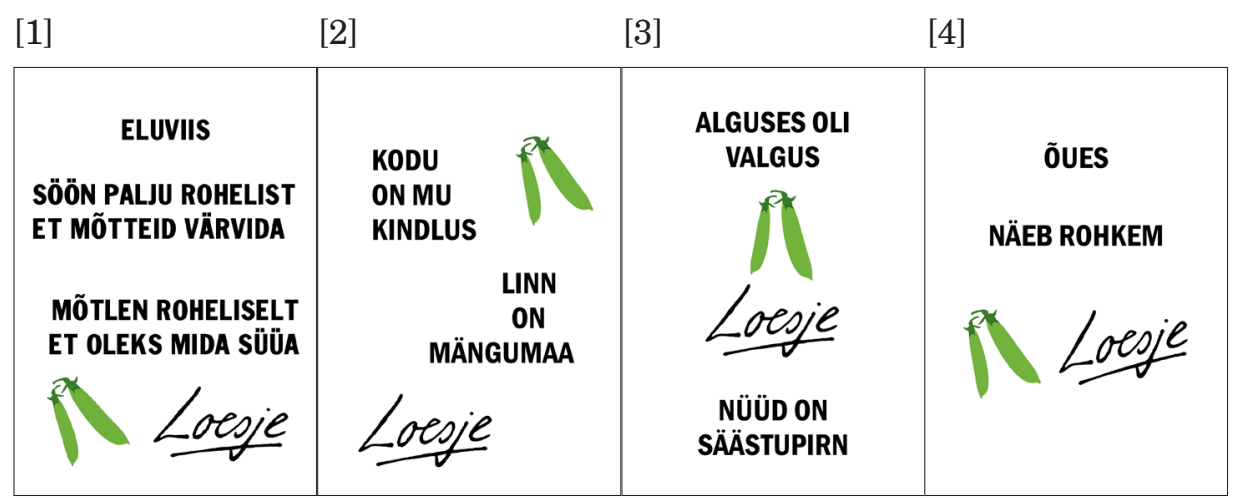

Posters' translations:

[1] Lifestyle: I eat a lot of green to colour my thoughts - and think green to have something to eat.

[2] Home is my castle - and city is playground.

[3] In the beginning was the light - and now energy saving lightbulbs.

[4] On the street you see more. 
It is obvious that a large share of graffiti texts in Tartu has been strongly influenced by international implications, and can be associated with cultural, political and economic changes caused by the rapid development of mass communication technology and greater mobility of people and goods. Global cultural attitudes, the characteristic features comprising cultural and semantic heterogeneity, multi-vocality, intentional fragmentation have been concurrent with postmodernism at the (modernism-)critical cultural era, the beginning of which is considered to be in the $1960 \mathrm{~s}$, and the peak-time in the late $1970 \mathrm{~s}$ and early 1980s. Postmodernism is connected with phenomenological hermeneutics and the social construct of reality, and relevance is given to the phenomenological fact that any text (written or presented as a social act) always has a context, and all objects of understanding have a temporal mode of existence, therefore, they are never static nor timeless but always history-specific and changing (Anttonen 2005: 20). All this can also be applied to graffiti. The subject matter of the anonymous street graffiti and the posters of Loesje youth group is extremely diverse and strongly juxtaposed with the socio-cultural surroundings which entails both local and global aspects.

\section{In conclusion}

Short-term fieldwork in Tartu confirmed the contact points between the lore of sayings and graffiti. The use of proverbs and sayings in the (textual) creations of street art broadens the applications of paremia and is definitely one of the ways to look at the surrounding everyday life, either at the individual or group level.

The novel content of proverbs and sayings and their somewhat different functions reflect traditions and improvisations, creativity and playfulness. Classical proverbs recorded in the three-volume academic publication "Eesti vanasõnad" ('Estonian Proverbs') cannot be found on the walls of Tartu, yet it is interesting to recognise the old form in the creation of new texts. The brief and powerful proverbial format - the cultural experience obtained by the user - is filled with new, socially sensitive content. This means that we could talk about proverbatavism in graffiti - the use of the paremic form can be defined as an unexpected re-emergence and new life of distant ancestors. The scatological, aggressive, obscene, sexual and provocative yet often humorous sub-tone of latrinalia, which is very frequently expressed in e.g. modifications of proverbs or pun rhymes, has been explained, from the psycho-analytical perspective, with the subconscious need to alleviate taboo themes and show resistance (see Nierenberg 1994: 556). Deciding which are the best paremic pieces of street graffiti in Tartu, there is no 
doubt that the application of serious author's quotations, modified and wittily reshaped proverbs adds authority and an intelligent dimension to the illegal graffiti, an offence against the law. And although the share of such meaningful texts which amiably catch the eyes of passers-by is actually marginal in the entirety of graffiti, it is somewhat surprising that they do exist.

A researcher needs to consider a number of aspects. Undoubtedly, as many other folklore forms of today, graffiti disappears and is changed quickly, causing problems in recording the material, yet it also indicates that graffiti is a dynamic, context- and time-centred cultural phenomenon.

The analysis of paremic graffiti-texts as social communication should definitely apply context-centred methods which give consideration to the social context (i.e. who creates for whom, where, when, for what reason, what is the receiver's cultural potential to interpret the graffiti text), and consider the connection that graffiti has with other domains and other forms of art. Paremic text in graffiti often involves and supports the elements of pop-culture and helps to fill the human, philosophical, socio-political, self-expressive and sometimes very aggressive and protest-minded aspirations of the author of the particular graffiti text. Graffiti as a multi-modal written cultural form is open, flexible and adaptable to the surrounding reality.

The paremic material is indeed conspicuous in the street art of Tartu partly due to the fact that among graffiti artists there are many conscious, missionoriented university and art school students whose actions are inherently carefully premeditated.

The graffiti-texts in Tartu evoke societal and cultural implications, and the good aphoristic form, intrinsic to paremia, poetic way of expression - harmony, rhymes - help, in some cases, better to convey the truth in graffiti. This was, for example, expressed in the graffiti under the Kroonuaia Bridge in 1997, where next to the picture there was the sentence "In graffiti veritas". Whose truth is it? What kind of truth is it? Does the author know the whole truth, can someone also guess it and can it simply touch someone? Naturally, it can happen the way it often happens when attempting to interpret literary works - the truth hidden in the graffiti becomes much bigger than the author could initially ever guess.

Photo by Tatjana Lissitsina 1997 (ERA, VF 3163).

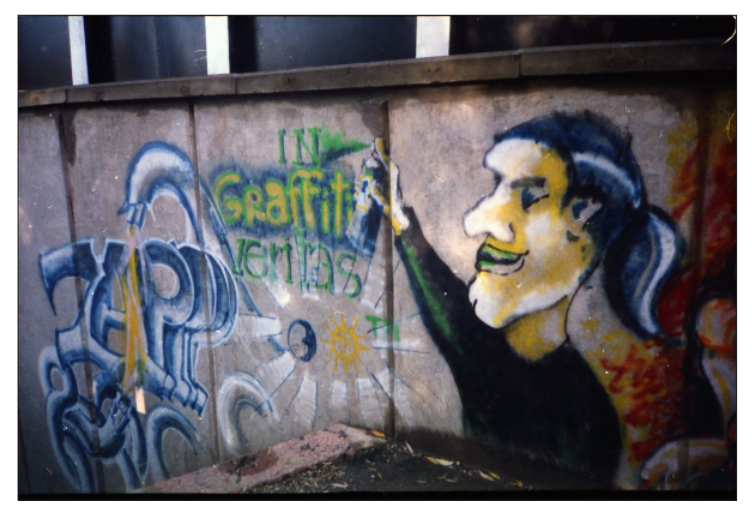




\section{References}

Anttonen, Pertti J. 2005. Folklore, modernity, and postmodernism: A theoretical overview. In: Tradition through modernity: Postmodernism and the nation-state in folklore scholarship. Studia Fennica Folkloristica 15. Helsinki: Finnish Literature Society, pp. $17-26$.

Bauman, Richard 1992. Genre. In: R. Bauman (ed.) Folklore, cultural performances, and popular entertainments: A communications-centered handbook. New York, Oxford: Oxford University Press, pp. 53-59.

Ben-Amos, Dan 1971. Toward a definition of folklore in context. Journal of American

Folklore 84, pp. 3-15.

Ben-Amos, Dan 2009. Kommunikatsioon ja folkloor. Sator 9. [Communication and folklore. Sator 9.] Tartu: Eesti Kirjandusmuuseumi Teaduskirjastus, Eesti Folkloori Instituut.

Dundes, Alan 1966. Here I sit - A Study of American latrinalia. The Kroeber Anthropological Society Papers 34, pp. 91-105.

Fiske, John 1990 [1982]. Introduction to communication studies. London \& New York: Rotledge.

Gnadenteich, Uwe 2011. Talentide linn: nulltolerants. [City of talents: zero tolerance.] In: Tallinna Postimees Online-versioon, 4th Nov. http://www.tallinnapostimees.ee/622788/ talentide-linn-nulltolerants/, last accessed on 1 May 2012.

Granbom-Herranen, Liisa 2010. Women's place in Finnish proverbs from childhood. Folklore: Electronic Journal of Folklore 46, pp. 95-110.

Jakobson, Roman 1981. Linguistics and poetics. In: S. Rudy (ed.) Selected writings III. Poetry of grammar and grammar of poetry. Hague, Paris, New York: Mouton.

Jokinen, Heikki. "Onni on suuri valkoinen seinä”. [Happiness is a big white wall.] In: J. Pöysä (ed.) Betoni kukkii: Kirjoituksia nykyperinteestä. [Concrete flowers: Writings on contemporary lore.] SKS tietolipas 115, pp. 199-214.

Krikmann, Arvo 1985. Vanasõnaparoodiatest. [On proverb parodies.] In: Keel ja Kirjandus 8, pp. 474-483.

Krikmann, Arvo 1997. Sissevaateid folkloori lühivormidesse. [Insights in the short forms of folklore.] In: Põhimõisteid, žanrisuhteid, üldprobleeme. [Consepts, genre relations, general problematics.] Tartu: Tartu Ülikooli Kirjastus.

Laaniste, Mari 2005. Piltide ja kirja keelest. [On the language of pictures and text.] In: Keel ja Kirjandus 8, pp. 617-629.

Laugaste, Eduard 1975. Eesti rahvaluule. [Estonian folklore.] Tallinn: Valgus.

Leete, Art 1995. Kriipamisest. [On scratching.] In: M. Kõiva (ed.) Lipitud-lapitud: Tänapäeva folkloorist. [Scratchy-patchy. Contemporary folklore.] Tartu: Eesti TA Eesti Kirjandusmuuseum, Eesti TA Eesti Keele Instituut, pp. 59-70. 
Litovkina, Anna \& Mieder, Wolfgang 2006. Old proverbs never die, they just diversify. A collection of anti-proverbs. Burlington: The University of Vermont, Veszprém: The Pannonian University of Veszprém.

Loesje Eesti. http://www.loesje.ee - last accessed on 1 May 2012.

Loesje 2006. Loesje: a course in creative writing. http://www.loesje.ee/books/loesje_manual_eng.pdf, last accessed on 1 May 2012.

Lõngus, Edward von 2012. EvL GENIUS - blog. http://evl-genius.blogspot.com. au/2012/01/miski-pole-olulisem.html, last accessed on 1 May 2012.

Mieder, Wolfgang 1991. "An apple a day keeps the doctor away": Traditional and modern aspects of english medical proverbs. In: Proverbium: Yearbook of International Proverb Scholarship 8, pp. 77-106.

Mieder, Wolfgang 2008. "Proverbs speak louder than words": Folk wisdom in art, culture, folklore, history, literature, and mass media. New York, Washington, D.C./Baltimore, Bern, Frankfurt am Main, Berlin, Brussels, Vienna, Oxford: Peter Lang.

Nierenberg, Jess 1994. Proverbs in graffiti: Taunting traditional wisdom. In: W. Mieder (ed.) Wise words: Essays on the proverb. New York \& London: Garland Publishing, Inc., pp. 543-561.

Palkov, Tõnis \& Sepisvart, Uku \& Siplane, Andres 2009. Haiguste ravi. Kontrollitud. Raamat tänavakunstist. [Cure of diseases. Tested. A book on street art.] Tallinn: Eesti Pakendiringlus.

Randviir, Anti 2008. Transdistsiplinaarsus objektides: ruumitähistus ja nimetamine grafitist hegemooniani. [Transdisciplinarity in objects: marking and naming room from graffity to hegemony.] In: Ü. Pärli \& E. Lepik (eds.) Nimetamise strateegiatest Eesti kultuuris. [On the naming strategies in Estonian culture.] Tartu: Tartu Ülikooli Kirjastus, pp. 13-39.

Rolston, Bill 1995. Drawing support 2: Murals of war and peace. Belfast: Beyond the Pale Publications.

Sarapik, Virve 2004. Pilt, kunst ja tekst (sissejuhatavat). [Picture, art and text (introductory).] In: E. Näripea \& V. Sarapik (eds.) Kunstiteaduslikke uurimusi: Studies on Art and Architecture: Studien für Kunstwissenschaft 1 (13), pp. 13-46.

Szpila, Grzegorz 2009. Humour as a tool in communicating proverbial wisdom in Polish graffiti. Acta Ethnographica Hungarica 54 (1), pp. 105-114.

Szpila, Grzegorz 2011. Mural wisdom. In: A. Witalisz (ed.) Papers on Culture, Language and Literature 3. Prace Naukowo-Dydaktyczne Państwowej Wyższej Szkoty Zawodowej w Krośnie 55. Krosno: PWSZ Krosno, pp. 321-333.

Szpila, Grzegorz 2012. Regulating the reality? Proverbs in Polish graffiti. In: L. Laineste \& D. Brzozowska \& W. Chłopicki (eds.) Estonia and Poland. Creativity and tradition in cultural communication, Vol. 1. Tartu: ELM Scholarly Press, pp. 269-284. 
Tammemäe, Helen 2012. Ornitoloogi pealehakkamine. [Undertaking of an ornithologist.] In: Mü̈̈rileht, 1th Feb. http://muurileht.ee/01-02-2012/ornitoloogi-pealehakkamine/, last accessed on 01 May 2012.

Taylor, Archer 1931. The proverb. Cambridge, Massachusetts: Harvard University Press.

Tedre, Ülo 1983. Sünkretism rahvaluules. [Syncretism in folklore.] Keel ja Kirjandus 7, pp. 337-341.

Tenjes et al. 2009 = Tenjes, Silvi \& Rummo, Ingrid \& Praakli, Kristiina 2009. Kommunikatiivse situatsiooni dünaamiline dimensioon. [The dynamic dimension of a communicative situation.] In: H. Metslang \& M. Langemets \& M. M. Sepper (eds.) Eesti Rakenduslingvistika Ühingu aastaraamat [Yearbook for the Society of applied linguistics] 5, pp. 267-285.

Tillman, Terry 1990. The Writings on the wall. Peace at the Berlin Wall. Santa Monica, CA: 22/7 Publishing Co.

Torop, Peeter 2008. Multimeedialisus. [Multimediality.] Keel ja Kirjandus 8, pp. 721-734.

Turner, Mark 1991. Reading minds: The study of English in the age of cognitive science. Princeton, New Jersey: Princeton University Press.

Voolaid, Kalle 1991. Graffiti: Ajalugu ja näited Tartu linnast: Kursusetöö. [Graffiti: History and Samples from Tartu: Course work.] Tartu Ülikooli eesti kirjanduse ja rahvaluule kateeder. [Tartu University, department of Estonian literature and folklore.] (Manuscript possesed by the author.)

Voolaid, Piret 2011a. Eesti mõistatused kui pärimusliik muutuvas kultuurikontekstis. [Estonian riddles as a heritage genre in the changing cultural context.] Tartu: Tartu Ülikooli Kirjastus.

Voolaid, Piret 2011b. Recent changes and reflections of true life events in Estonian riddles. In: A. Witalisz (ed.) Papers on Culture, Language and Literature 3. Prace Naukowo-Dydaktyczne Państwowej Wyższej Szkoły Zawodowej w Krośnie 55. Krosno: PWSZ Krosno, pp. 205-219.

Williams, Fionnuala 1991. "To kill two birds with one stone": variants in a war of words. Proverbium 8, pp. 199-201. 